\title{
EFFECTS OF GROWTH HABITS OF GRASSES ON WEED POPU- LATION AND DRY MATTER YIELD IN GRASS-LEGUME SWARDS
}

\author{
EFECTOS DE LOS HÁBITOS DE CRECIMIENTO DE PASTOS SOBRE LAS ADVENTICIAS \\ Y LOS RENDIMIENTOS EN PRADERAS DE GRAMÍNEAS Y LEGUMINOSAS
}

\author{
Anele, U.Y. ${ }^{1,2 *}$; Jolaosho, O.A. ${ }^{1}$; Arigbede, O.M. ${ }^{1,2}$; Olanite, J.A. ${ }^{1}$ and Onifade, O.S. ${ }^{1}$
}

'Department of Pasture and Range Management. College of Animal Science and Livestock Production. University of Agriculture. Abeokuta. Nigeria. *dryounganele@yahoo.com; yane@itw.uni-bonn.de ${ }^{2}$ Institute of Animal Science. University of Bonn. Bonn. Germany.

\section{AdDITIONAL KEYWORDS}

Andropogon tectorum. Brachiaria ruziziensis. Competition for resources. Pennisetum purpureum.

\section{SUMMARY}

A study was carried out over a period of two years to evaluate the ability of 12 grass-legume mixtures to compete with weeds over a 12-week period following planting in 2004 and after cutback in 2005. Plant height, leaf number, weed population and dry matter (DM) yields of weeds and grasses at 6 and 12 weeks after planting were recorded. Leaf number of the grasses increased slowly during the first 8 weeks after planting, then increased exponentially between 9 and 12 weeks, reaching 145 leaves/plant. The bunch-forming grasses had more $(p<0.05)$ leaves than the Brachiaria species. In the second year, leaf number reached 329 leaves/plant. Weed populations were prominent during the first 8 weeks after planting, with broadleaf weeds the most common in both 2004 and 2005. Mixtures containing $B$. ruziziensis recorded the greatest $(p<0.05)$ weed populations, and swards of $B$. ruziziensis- $T$. bracteolata consistently recorded the least $(p<0.05) D M$ yields of 281 and $326 \mathrm{~kg} / \mathrm{ha}$ at 12 weeks after planting in 2004 and 2005, respectively. Sward mixtures containing Pennisetum purpureum and Andropogon tectorum consistently had the greatest $(\mathrm{p}<0.05)$ yields $(1100-2000$ and $1500-2200 \mathrm{~kg} / \mathrm{ha}$ in 2004 and 2005). The population of weeds in the 2 years declined with increase in growing period.

\section{RESUMEN}

Durante un período de dos años, se evaluó la

\section{Palabras clave adicionales}

Andropogon tectorum. Brachiaria ruziziensis. Competencia por recursos. Pennisetum purpureum.

capacidad de 12 mezclas de gramíneas y leguminosas pratenses tropicales para competir con las adventicias durante 12 semanas después de la plantación en 2004 y después de un corte en 2005. Se registraron la altura de planta, número de hojas, la población de adventicias y la producción de materia seca (MS) de las adveenticias y mezclas de pastos en las semanas 6 y 12 después de la siembra. El número de hojas de las gramíneas pratenses aumentó lentamente durante las primeras 8 semanas después de la siembra, luego aumentó exponencialmente entre las 9 y 12 semanas, llegando a 145 hojas/planta. Las gramíneas de crecimiento erecto forman más hojas $(p<0.05)$ que las especies de Brachiaria. En el segundo año, el número de hojas alcanzó 329 hojas/planta. Las poblaciones de adventicias fueron superiores durante las primeras 8 semanas después de la siembra, siendo las de hoja ancha las más comunes en los años 2004 y 2005. Las mezclas con $B$. ruziziensis registraron la mayor $(p<0.05)$ población de adventicias, y la mezcla de $B$. ruziziensis- $T$. bracteolata registró el menor $(p<0.05)$ rendimiento de MS con 281 y $326 \mathrm{~kg} / \mathrm{ha}$ a las 12 semanas después de la plantación en 2004 y 2005, respectivamente. Mezclas que contengan Pennisetum purpureum y Andropogon tectorum siempre alcanzaron mayores $(p<0.05)$ rendimientos a las 12 semanas $(1100-2000$ y $1500-2200 \mathrm{~kg} \mathrm{MS} / \mathrm{ha}$ en 2004 y 2005). La población de adventicias en los 2 años disminuyó durante el crecimiento. 


\section{INTRODUCTION}

Many grasses, such as Panicum maximum, Pennisetum purpureum, Andropogon gayanus, Cynodon nlemfuensis and C. dactylon, have played prominent roles in forage research and livestock production in Nigeria (Mohammed-Saleem, 1994), as forages represent a major nutritional input for ruminant animal production. They are often grown in association with legumes to improve both quality and quantity of feed for ruminant animals (Smith et al., 1992).

Weed infestation is a major concern in the management of grass-legume mixtures, especially during the early stages of establishment (Peters and Linscott, 1988), before the plants are well established and able to compete effectively with the weeds. Weeds are always a serious problem in newly established pastures, especially when weed control is not given consideration during pasture establishment or in management of natural grasslands (Lugo et al., 1995). Most weed species grow rapidly and compete with the sown pasture plants for light, water and nutrients, resulting in very serious reduction in pasture plant population and in particular the legume population (Semb, 1996). Teitzel and Middleton (1980) concluded that, with adequate attention to seed-bed preparation, soil fertility and pasture establishment practices, vigorous pastures could readily be obtained and managed to overcome most weed problems. Any plant factor that hastens ground cover, height advantage and shading by the crop enhances competitive ability (Lyon et al., 1996).

The growth of grasses, either sodforming or bunch-forming is boosted when in association with legumes. Sod-forming grasses produce either rhizomes or stolons, each being a modified stem, which extends laterally enabling the grass to develop a firm sod. Bunch grasses on the other hand are grasses that usually grow as singular plants in clumps, tufts, or bunches, rather than forming sods. Grass/legume mixed swards are noted to play key roles in provision of year - round high quality feed for the ruminant animals as well as improving the soil nutrient status. The most important role of legumes in pastures is maintenance of the quality of pasture in the dry season which represents the most critical period in the feeding of ruminant animals. Grass/legume mixtures are important for the purpose of maintaining feed availability into the late dry season (Sleugh et al., 2000). The increase in the fodder yield under mixed sward of grass/ legume is probably due to additional supply of nitrogen as a result of the atmospheric nitrogen fixed by the legumes (Sleugh et al., 2000). Legumes grown in association with grasses have been reported to boost the growth of grasses and improve their quality particularly protein. Sod-forming grasses have characteristic spreading growth habits which later form layers of grassland as growth continues. Bunch-forming grasses have erect shots with long internodes arising from basal shoots with short internodes. In general, sod-forming and bunch-forming grasses differ in both growth habit and ability to control weeds.

\section{MATERIALS AND METHODS}

The experiment was conducted at the Teaching and Research Farm, University of Agriculture, Abeokuta(UNAAB), Nigeria. The site lies within the derived savannah zone $\left(7^{\circ} \mathrm{N}, 3.5^{\circ} \mathrm{E}\right)$. Rainfall is the major factor influencing crop establishment in this environment, with the rainy season extending from March to October and the highest rainfall in June (figure 1).

A total of 12 treatments consisting of grass-legume mixed swards representing all combinations of 2 legumes and 6 grasses were planted in July 2004. The legumes used were Tephrosia bracteolata and Stylosanthes hamata 'Verano'. The grasses used were 3 sod-forming types (Brachiaria decumbens, B. ruziziensis, A. tectorum) and 


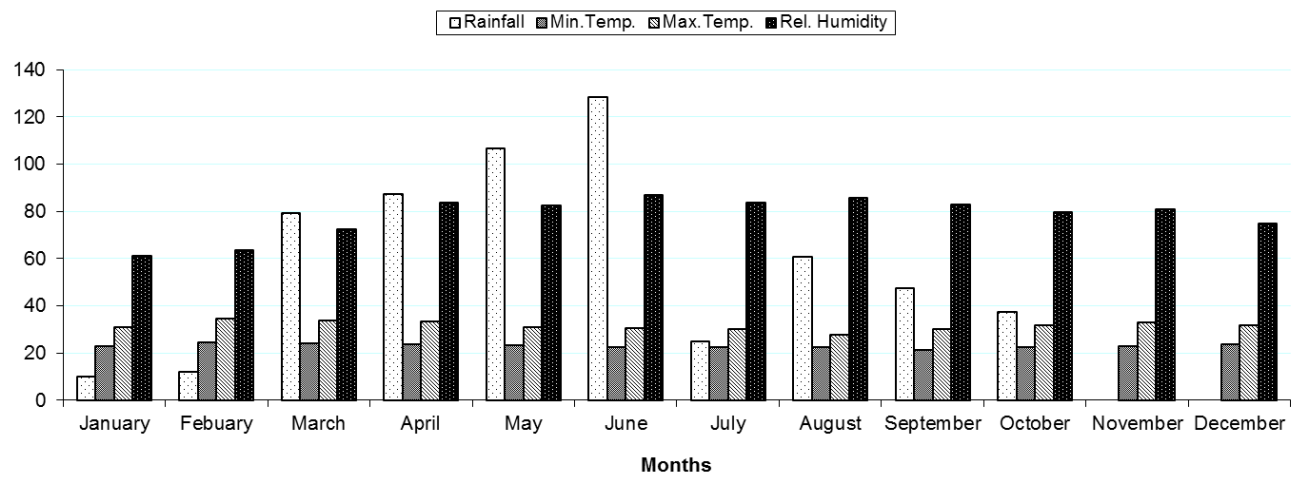

Source: Agrometrological Unit, University of Agriculture, Abeokuta

Figure 1. Average monthly rainfall $(\mathrm{mm})$, minimum temperature $\left({ }^{\circ} \mathrm{C}\right)$, maximum temperature $\left({ }^{\circ} \mathrm{C}\right)$ and relative humidity (\%) recorded in the University of Agriculture, Abeokuta (20042005).(Precipitación mensual, temperaturas $\left({ }^{\circ} \mathrm{C}\right)$ mínima y máxima, humedad relativa (\%); valores medios registrados en la University of Agriculture, Abeokuta (2004-2005)).

3 bunch-forming types ( $P$. purpureum, $P$. maximum 'Ntchisi' and Digitaria smutsii). These 12 treatments were replicated 3 times to give a total of 36 experimental plots, each measuring $3 \times 3 \mathrm{~m}$, laid out in a randomised complete block design. Ten composite soil samples were randomly collected from the plots before the commencement of planting in May 2004 and at the commencement of data collection at the onset of the rains in May 2005 at depths of 0-15 and $15-30 \mathrm{~cm}$ to represent the top and subsoil, respectively. The samples were separately bulked per replicate, mixed thoroughly and sub-samples taken for analysis to determine the pre- and post-planting nutrient status of the soil. The results obtained are shown in table $\mathbf{I}$.

The land was cleared by clean-weeding the area using hoe and cutlass to have minimal disturbance of the top soil. Fertiliser (NPK 15:15:15) was applied as a side dressing at the rate of $175 \mathrm{~kg} / \mathrm{ha}$ on August 29, 2004, when yellowing of leaves was noticed on the plants. Plant heights of both grasses and legumes were measured weekly with the aid of a measuring tape in a $1 \mathrm{~m}^{2}$ quadrat at 3 locations in each plot. The type and population of weeds and numbers of leaves on the individual forage grasses and legumes were recorded for each quadrat. The average leaf number of forage plants and number of weeds in each plot were calculated.

The plots were harvested (at $15 \mathrm{~cm}$ above ground level) at 12 weeks after planting (WAP) for dry matter (DM) yield estimation. The plants were cut back at the commencement of rains in the following year in May 2005.

Data collected were subjected to analysis of variance using the statistical procedures of SAS-GLM (Littell et al., 1991). Means were compared by applying the probability of difference (PDIFF) option in the general linear model procedure.

\section{RESULTS}

Soils were slightly acidic with $\mathrm{pH}$ increasing slightly with depth and between 2004 and 2005 (table I). Total N values increased slightly from $0.13 \%$ in 2004 to 0.16 $\%$ in 2005, while organic carbon levels declined with time with greater reduction in the topsoil. All exchangeable cation levels decreased with depth except for sodium. The soils had very high proportion of sand 
which ranged from 94.3 to $92.8 \%$ for depths of 0-15 and $15-30 \mathrm{~cm}$, respectivley in 2004 and 92.8 to $91.4 \%$ for depths of $0-15$ and 15 $30 \mathrm{~cm}$, respectively in 2005 . The silt and clay contents ranged between 4-8\% and 1-2\%, respectively in both years.

In 2004, leaf production of grasses increased slowly until 8 WAP, with an exponential rise between 9 and 12 weeks, reaching a peak of 145 leaves/plant by 12 WAP (table II). There were significant differences $(p<0.001)$ in the leaf production of the grasses with the highest production at the twelfth week and the least at week one. During 2005, grass leaf production increased linearly with time reaching 329 leaves/plant. The leaf production in 2005 was significant $(p<0.001)$ and followed similar trend as observed in 2004. There was no significant difference $(p>0.05)$ in the

Table I. Physico-chemical characteristics of the soil samples prior to planting. (Características físico-químicas de las muestras de suelo antes de la siembra).

\begin{tabular}{lcccc}
\hline & \multicolumn{2}{c}{2004} & \multicolumn{2}{c}{2005} \\
& $0-15$ & $15-30$ & $0-15$ & $15-30$ \\
& $(\mathrm{~cm})$ & $(\mathrm{cm})$ & $(\mathrm{cm})$ & $(\mathrm{cm})$ \\
\hline Chemical properties & & & & \\
$\mathrm{pH}\left(\mathrm{H}_{2} \mathrm{O}\right)$ & 5.76 & 5.84 & 5.89 & 5.97 \\
Total N (\%) & 0.13 & 0.12 & 0.15 & 0.16 \\
Organic carbon (\%) & 3.69 & 3.69 & 2.98 & 3.52 \\
C:N ratio & 28.4 & 28.6 & 19.9 & 22.0 \\
Available P (mg/kg) & 84.0 & 81.4 & 75.1 & 80.1 \\
Acidity (cmol/kg) & 0.23 & 0.33 & 0.33 & 0.37 \\
CEC & 1.79 & 1.42 & 1.68 & 1.42 \\
& & & & \\
Exchangeable cations & $(\mathrm{cmol} / \mathrm{kg})$ & & \\
Sodium & 0.20 & 0.20 & 0.21 & 0.22 \\
Potassium & 0.20 & 0.18 & 0.19 & 0.16 \\
Calcium & 0.87 & 0.61 & 0.80 & 0.65 \\
Magnesium & 0.52 & 0.43 & 0.48 & 0.39 \\
Particle size & & & & \\
Sand (\%) & 94.3 & 92.8 & 92.8 & 91.4 \\
Silt (\%) & 4.4 & 5.9 & 5.9 & 7.2 \\
Clay (\%) & 1.3 & 1.3 & 1.4 & 1.5 \\
\hline
\end{tabular}

population of the weeds in 2004. Broadleaf weeds were the most common (10-26 plants/ $\mathrm{m}^{2}$ ) while spiderworth (Commelina spp.) had the lowest counts in 2004. Populations of all weeds tended to decline with time in the first year (2004). With the exception of grass (weed), all the other weeds had the lowest population at the twelfth week.

While weed populations in 2005 were higher than in 2004, broadleaf weeds were again most common (23-53 plants $\left./ \mathrm{m}^{2}\right)$ and spiderworth (Commelina spp.) the least common. In 2005, yields of grasses exceeded those of weeds throughout. In general, as the numbers of leaves on grasses increased, the numbers of weeds decreased. There appeared to be a quadratic rather than linear effect on the population of the weeds across weeks. There were significant differences in the population of the sedges, spiderworth (Commelina spp.) and broadleaf with $\mathrm{p}$ value of 0.001 .

The weed populations in the different grass-legume plots are shown in table III. There were significant differences in all the variables determined with $\mathrm{p}$ values ranging between 0.001 and 0.002 . In both 2004 and 2005 , plots with $B$. ruziziensis/T. bracteolata had the highest broadleaf weed population while the lowest population was in A. tectorum/T. bracteolata in 2004 and plots of $P$. maximum/T. bracteolata and $A$. tectorum/T. bracteolata in 2005. The highest grass (weed) population was observed in plots of $P$. purureum/S. hamata in 2004 and B. ruziziensis/T. bracteolata in 2005 while the lowest population was observed in plots of $P$. maximum $/ T$. bracteolata in 2004 and $P$. purpureum/T. bracteolata in 2005. For sedges and spiderworth (Commelina spp.), the highest population was observed in the plot of $D$. smutsii/S. hamata in 2004 and plots of $B$. ruziziensis/T. bracteolata and B. ruziziensis/S. hamata in 2005. The lowest population was observed in plots of $B$. decumbens $/ T$. bracteolata and A. tectorum/T. bracteolata, respectively in 2004 while the lowest in 2005 
Table II. The effect of length of growth (weeks) on the population (plants $\left./ \mathrm{m}^{2}\right)$ of weeds and number ofleaves per plant of companion forage grasses in 2004 and 2005. (Efecto de la duración de crecimiento (semanas) en la población (plantas $/ \mathrm{m}^{2}$ ) de adventicias y el número de hojas por planta de gramíneas forrajeras en 2004 y 2005).

\begin{tabular}{|c|c|c|c|c|c|c|c|c|c|c|}
\hline & $\begin{array}{l}\text { Leaves } \\
\text { (weed) }\end{array}$ & Grass & $\begin{array}{l}2004 \\
\text { Sedges } \\
\text { worth }\end{array}$ & $\begin{array}{l}\text { Spider- } \\
\text { leaf }\end{array}$ & Broad- & $\begin{array}{l}\text { Leaves } \\
\text { (weed) }\end{array}$ & Grass & $\begin{array}{l}2005 \\
\text { Sedges } \\
\text { worth }\end{array}$ & $\begin{array}{c}\text { Spider- } \\
\text { leaf }\end{array}$ & Broad- \\
\hline \multicolumn{11}{|l|}{ Week } \\
\hline 1 & $4.0^{i}$ & 9.0 & 10.0 & 3.0 & 22.7 & $126^{i}$ & 16.0 & $13.3^{g}$ & $1.3^{\mathrm{g}}$ & $23.0^{d}$ \\
\hline 2 & $7.3^{\mathrm{hi}}$ & 9.0 & 11.3 & 3.3 & 26.0 & $135^{\mathrm{hi}}$ & 19.3 & $16.0^{f g}$ & $3.6^{\text {de }}$ & $34.0^{\mathrm{cd}}$ \\
\hline 3 & $8.0^{\mathrm{hi}}$ & 10.0 & 9.3 & 3.6 & 25.0 & $156^{\text {gh }}$ & 21.0 & $19.3^{\text {defg }}$ & $3.9^{c d}$ & $35.0^{\text {cd }}$ \\
\hline 4 & $11.3^{\text {ghi }}$ & 13.0 & 11.3 & 4.0 & 20.0 & $179^{f g}$ & 25.0 & $32.3^{\mathrm{ab}}$ & $3.9^{\mathrm{cd}}$ & $53.0^{a}$ \\
\hline 5 & $16.0^{\text {fgh }}$ & 7.0 & 10.3 & 4.0 & 19.3 & $193^{\text {ef }}$ & 25.6 & $37.0^{\mathrm{a}}$ & $4.7^{c}$ & $52.0^{\mathrm{ab}}$ \\
\hline 6 & $19.7^{\text {efg }}$ & 8.0 & 7.3 & 4.0 & 19.0 & $209^{e}$ & 22.6 & $28.3^{b c}$ & $9.6 a$ & $50.0^{\mathrm{ab}}$ \\
\hline 7 & $23.3^{e f}$ & 7.0 & 7.7 & 2.6 & 19.3 & $238^{d}$ & 21.0 & $26.3^{\mathrm{bcd}}$ & $9.3^{\mathrm{a}}$ & $50.0^{\mathrm{ab}}$ \\
\hline 8 & $28.7^{e}$ & 9.0 & 7.3 & 3.7 & 20.0 & $253^{d c}$ & 19.0 & $25.0^{\text {bcd }}$ & $6.3^{b}$ & $49.6^{\mathrm{ab}}$ \\
\hline 9 & $47.7^{d}$ & 10.0 & 7.0 & 2.3 & 20.0 & $269^{b c}$ & 20.6 & $24.0^{\text {cde }}$ & $3.9^{\mathrm{cd}}$ & $49.0^{\mathrm{ab}}$ \\
\hline 10 & $67.7^{c}$ & 9.0 & 6.0 & 2.0 & 18.0 & $276^{b c}$ & 21.0 & $22.6^{\text {cdef }}$ & $3.6^{\mathrm{de}}$ & $46.0^{\mathrm{abc}}$ \\
\hline 11 & $123.0^{\mathrm{b}}$ & 10.0 & 6.0 & 2.0 & 17.0 & $294^{\mathrm{ab}}$ & 23.0 & $18.6^{\text {defg }}$ & $2.9^{e f}$ & $44.6^{\mathrm{abc}}$ \\
\hline 12 & $145.0^{\mathrm{a}}$ & 10.0 & 6.0 & 1.6 & 16.0 & $329^{a}$ & 21.0 & $16.3^{\mathrm{efg}}$ & $2.6^{f}$ & $39.3^{b c}$ \\
\hline SEM & 1.86 & 1.50 & 1.23 & 0.85 & 2.0 & 5.30 & 2.13 & 1.51 & 0.20 & 2.50 \\
\hline p-values & 0.001 & 0.375 & 0.017 & 0.439 & 0.048 & 0.001 & 0.194 & 0.001 & 0.001 & 0.001 \\
\hline
\end{tabular}

abcdighiMeans with different superscript along columns are significantly different.

were plots of $P$. purpureum/T. bracteolata and $P$. purpureum/S. hamata for the sedges and $B$. decumbens $/ T$. bracteolata for spiderworth (Commelina spp).

During the first 6 weeks after planting in 2004, dry matter yields of broadleaf weeds were generally higher than those of other weeds averaging about $590 \mathrm{~kg} / \mathrm{ha}$. It was also higher than the DM yields of the sown grasses. Mixed sward of B. ruziziensis/T. bracteolata recorded the higest DM yield of both grass (weed) and sedges while the lowest DM yield of both weeds were observed in mixed swards of $D$. smutsii/S. hamata and $P$. purpureum/S. hamata, respectively. Mixed sward of $B$. decumbens/ $T$. bracteolata and $B$. decumbens $/ S$. hamata recorded both the lowest and highest DM yields of spiderworth (Commenlina spp), respectively. However, by 12 WAP, grass yields generally exceeded those of the weeds, especially for A. tectorum and $P$. purpureum (figure 2).

By 12 WAP in 2004, mixed swards of $A$. tectorum and $P$. purpureum with either $T$. bracteolata or $S$. hamata had reached yields of $1100-2000 \mathrm{~kg} / \mathrm{ha}$, while $B$. ruziziensis was still lowest at $250-350 \mathrm{~kg} / \mathrm{ha}$. Total herbage harvested from the plots ranged between 1500-2600 kg/ha. Higher yields were observed in mixed swards of the sown grasses with $T$. bracteolata than those with S. hamata.

In 2005 , the pattern was similar with mixed swards of $A$. tectorum and $P$. purpureum having highest yields at 12 weeks after cut back (1500-2200 kg/ha), while corresponding values for $B$. ruziziensis were $350 \mathrm{~kg} / \mathrm{ha}$, other grasses were intermediate (figure 3). The highest DM yield of $829 \mathrm{~kg} /$ ha for broadleaf and $403 \mathrm{~kg} / \mathrm{ha}$ for grass (weed) was recorded for mixed swards of $B$. ruziziensis/S. hamata and $P$. maximum $/ S$. hamata, respectively. Mixed sward of $A$. 
ANELE, JOLAOSHO, ARIGBEDE, OLANITE AND ONIFADE

Table III. The effect of sward type on weed population (plants $/ \mathrm{m}^{2}$ ) in 2004 and 2005. (El efecto del tipo de pradera mixta en la población (plantas $/ \mathrm{m}^{2}$ ) de adventicias en el 2004 y 2005).

\begin{tabular}{|c|c|c|c|c|c|c|c|c|}
\hline \multirow[b]{2}{*}{$\begin{array}{l}\text { Forage } \\
\text { mixture }\end{array}$} & \multicolumn{4}{|c|}{2004} & \multicolumn{4}{|c|}{2005} \\
\hline & Broadleaf & $\begin{array}{c}\text { Grass } \\
\text { (weed) }\end{array}$ & Sedges & $\begin{array}{l}\text { Spider- } \\
\text { worth }\end{array}$ & Broadleaf & $\begin{array}{l}\text { Grass } \\
\text { (weed) }\end{array}$ & Sedges & $\begin{array}{l}\text { Spider- } \\
\text { worth }\end{array}$ \\
\hline BR-TB & $23.3^{a}$ & $9.3^{a b}$ & $8.5^{\mathrm{ab}}$ & $2.2^{\mathrm{ab}}$ & $30.3^{a}$ & $20.3^{a}$ & $18.4^{a}$ & $5.2^{b c}$ \\
\hline BD-TB & $13.3^{b}$ & $6.4^{\mathrm{ab}}$ & $4.9^{c}$ & $1.3^{\text {cde }}$ & $22.7^{\mathrm{cd}}$ & $19.5^{\mathrm{ab}}$ & $8.4^{\mathrm{cd}}$ & $2.6^{d}$ \\
\hline АТ-ТВ & $13.1^{b}$ & $5.3^{b}$ & $5.1^{\mathrm{b}}$ & $1.9^{\mathrm{abc}}$ & $21.8^{d}$ & $14.6^{\mathrm{cd}}$ & $8.6^{\mathrm{cd}}$ & $4.3^{c d}$ \\
\hline PP-TB & $13.1^{b}$ & $5.3^{b}$ & $5.1^{\mathrm{b}}$ & $2.1^{\mathrm{ab}}$ & $22.3^{d}$ & $10.3^{d}$ & $7.9^{d}$ & $5.0^{\mathrm{bc}}$ \\
\hline PM-TB & $13.3^{b}$ & $5.1 b$ & $8.6^{\mathrm{ab}}$ & $2.3^{\mathrm{ab}}$ & $21.8^{d}$ & $10.6^{d}$ & $9.8^{\mathrm{cd}}$ & $7.6^{a}$ \\
\hline DS-TB & $14.3^{b}$ & $6.2^{\mathrm{ab}}$ & $8.3^{\mathrm{ab}}$ & $2.2^{\mathrm{ab}}$ & $24.9^{\mathrm{bcd}}$ & $12.0^{d}$ & $12.1^{\mathrm{bcd}}$ & $6.3^{a b c}$ \\
\hline DS-SH & $18.1^{\mathrm{ab}}$ & $7.6^{a b}$ & $10.0^{a}$ & $2.4^{\mathrm{a}}$ & $28.3^{a b}$ & $14.6^{\mathrm{cd}}$ & $16.1^{a b}$ & $6.9^{a b}$ \\
\hline PM-SH & $17.2^{\mathrm{ab}}$ & $8.9^{a b}$ & $6.2 b$ & $1.6^{\mathrm{bcd}}$ & $26.9^{a b c}$ & $16.9^{\mathrm{abc}}$ & $8.7^{\mathrm{cd}}$ & $5.1^{b c}$ \\
\hline PP-SH & $18.6^{\mathrm{ab}}$ & $10.0^{a}$ & $5.0 \mathrm{~b}$ & $1.1^{\mathrm{de}}$ & $28.6^{a b}$ & $11.1^{d}$ & $7.9^{\mathrm{d}}$ & $7.7^{a}$ \\
\hline AT-SH & $16.2^{\mathrm{ab}}$ & $7.4^{\mathrm{ab}}$ & $6.9^{\mathrm{ab}}$ & $0.70^{e}$ & $26.6^{a b c}$ & $10.3^{d}$ & $9.6 c^{d}$ & $4.6^{\mathrm{cd}}$ \\
\hline BD-SH & $18.3^{\mathrm{ab}}$ & $7.3^{\mathrm{ab}}$ & $7.3^{\mathrm{ab}}$ & $1.2^{\text {cde }}$ & $29.3^{a}$ & $14.9^{\mathrm{bcd}}$ & $15.6^{\mathrm{ab}}$ & $4.3^{c d}$ \\
\hline BR-SH & $16.6^{\mathrm{ab}}$ & $8.6^{\mathrm{ab}}$ & $8.1^{\mathrm{ab}}$ & $2.3^{\mathrm{ab}}$ & $27.3^{\mathrm{ab}}$ & $14.3^{\mathrm{cd}}$ & $13.9^{\mathrm{abc}}$ & $8.3^{a}$ \\
\hline SEM & 1.30 & 0.82 & 0.72 & 0.15 & 0.83 & 0.93 & 1.14 & 0.41 \\
\hline$p$-values & 0.001 & 0.002 & 0.001 & 0.001 & 0.001 & 0.001 & 0.001 & 0.001 \\
\hline
\end{tabular}

abcde Means with different superscript along columns are significantly different.

$\mathrm{BR}=B$. ruziziensis; $\mathrm{TB}=T$. bracteolate $; \mathrm{BD}=B$. decumbens; $\mathrm{AT}=A$. tectorum; $\mathrm{PP}=P$. purpureum; $\mathrm{PM}=$ $P$. maximum; $\mathrm{DS}=\mathrm{D}$. smutsii; $\mathrm{SH}=\mathrm{S}$. hamata.

tectorum/T. bracteolata recorded the lowest DM yield of both broadleaf and grass (weed). Mixed sward of $P$. purpureum/T. bracteolata had the lowest DM yield of sedges and spiderworth (Commenlina) while the highest DM yield was observed in mixed swards of $A$. tectorum/S. hamata and $B$. ruziziensis/T. bracteolata, respectively.

Total herbage harvested from the plots ranged between $1200-3300 \mathrm{~kg} / \mathrm{ha}$. Contrary to the observation in 2004 , higher yields were observed in mixed swards of the sown grasses with $S$. hamata than those with $T$. bracteolata.

\section{DISCUSSION}

This study has shown that weeds provided significant competition for grasses during the first 6 weeks after planting, but the grasses overcame this competition by 12 weeks after planting. This emphasizes the importance of clean, weed-free seedbeds, so that grass seedlings can become established with minimal competition from fast-growing weeds. By 12 weeks, the grass had produced sufficient canopy cover which was adequate to suppress weeds as shown by the rapid surge in leaf production between 9 and 12 weeks. The data suggest that an equilibrium level of leaves $/ \mathrm{m}^{2}$ (145) was reached at this time. However, in the second year, a higher leaf number (309 leaves $/ \mathrm{m}^{2}$ ) was reached. The importance of weed control in pasture production should not be underestimated, especially when one considers the high investment associated with producing high quality forages for the livestock industry which has resulted in developing countries relying heavily on natural pastures.

Although there was insignificant difference in the soil physico-chemical characteristics during the two-year period, adjusting the soil $\mathrm{pH}$ and nutrient levels according to soil test recommendations can 


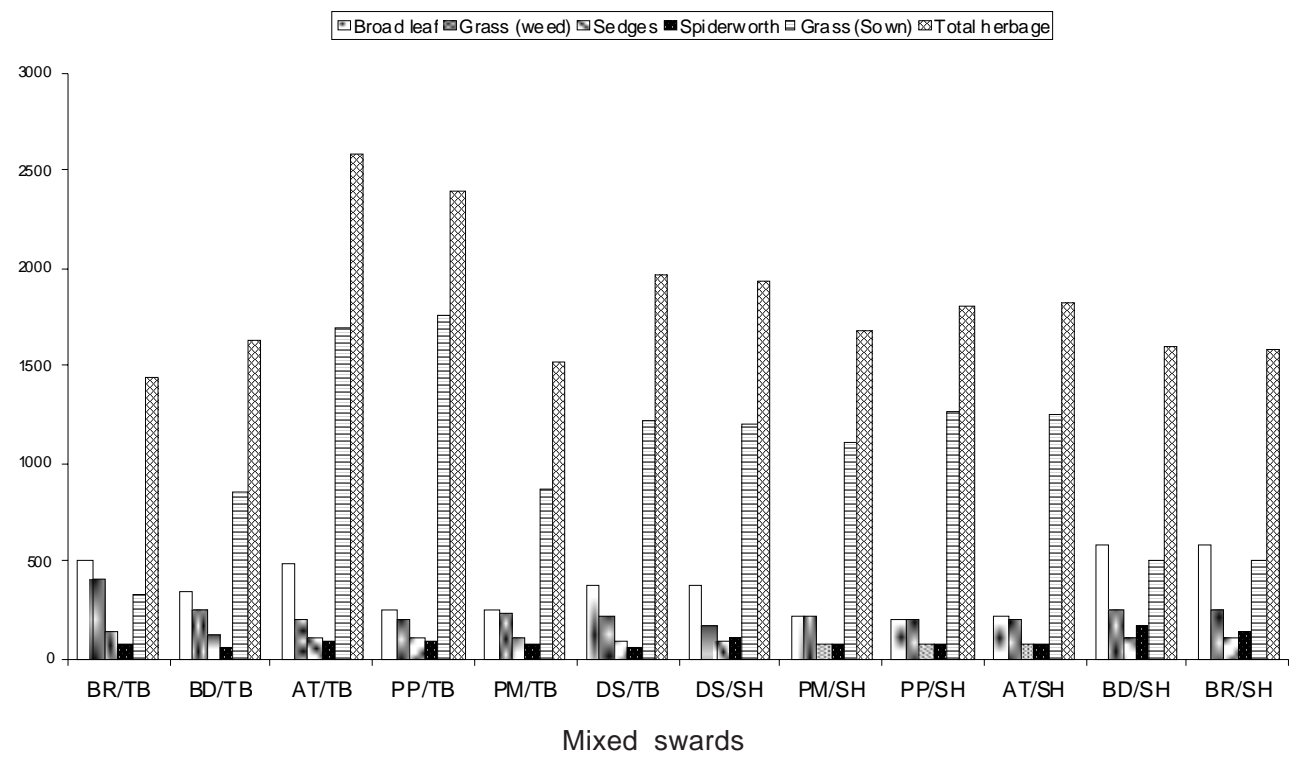

Figure 2. Dry matter yield $(\mathrm{kg} / \mathrm{ha})$ of weed types and companion forage grasses $(B R=\mathrm{B}$. ruziziensis; $T B=\mathrm{T}$. bracteolata; $A T=\mathrm{A}$. tectorum; $P P=\mathrm{P}$. purpureum; $P M=\mathrm{P}$. maximum; $D S=$ D. smutsii; $S H=\mathrm{S}$. hamata) 12 weeks after planting in 2004. (Rendimiento de materia seca $(\mathrm{kg} /$ ha) de los tipos de malas hierbas y pastos de forraje de compañía $(B R=B$. ruziziensis, $\mathrm{TB}=T$. bracteolata; $\mathrm{AT}=A$. tectorum; $\mathrm{PP}=P$. purpureum; $\mathrm{PM}=P$. máxima; $\mathrm{DS}=\mathrm{D}$. smutsii; $\mathrm{SH}=\mathrm{S}$. hamata) 12 semanas después de la siembra en 2004).

help increase the stand density of desirable forage species.

The pattern of leaf production with time is in conformity with the growth pattern of plants described by (Bonner and Galson, 1959) and (Haynes, 1980), that plant growth follows an early period of slow growth, a central rapid growth and a final period of slow growth.

Broadleaf weeds were obviously the main competitors for the sown grasses, especially during the establishment phase. This is important as selective herbicides could be used to spray these weeds in extreme circumstances without damaging the sown grass seedlings. Weed control is more critical during the first year than any other period of forage production. Forage seedlings grow slowly and are easily overcome by rapidly growing weeds (Lawal,
2000). Research has shown that some broadleaf weed seedlings are capable of growing five times more rapidly than certain legume seedlings. In addition to yield losses, weeds can also lower forage quality, increase the incidence of disease and insect problems, cause premature stand loss, and create harvesting problems. Some weeds are unpalatable to livestock or, in some cases, may be poisonous (Lawal, 2000).

The results from the study revealed that the various grass-legume mixtures differed in their ability to control weed populations. The ability of a grass-legume sward to compete with weeds depends mainly on its ability to grow quickly and form a canopy, which will produce a shading effect on the weed seedlings (Zannone et al., 1986). The mixed sward of $B$. decumbens and $T$. bracteolata significantly reduced the population of 


\section{ANELE, JOLAOSHO, ARIGBEDE, OLANITE AND ONIFADE}

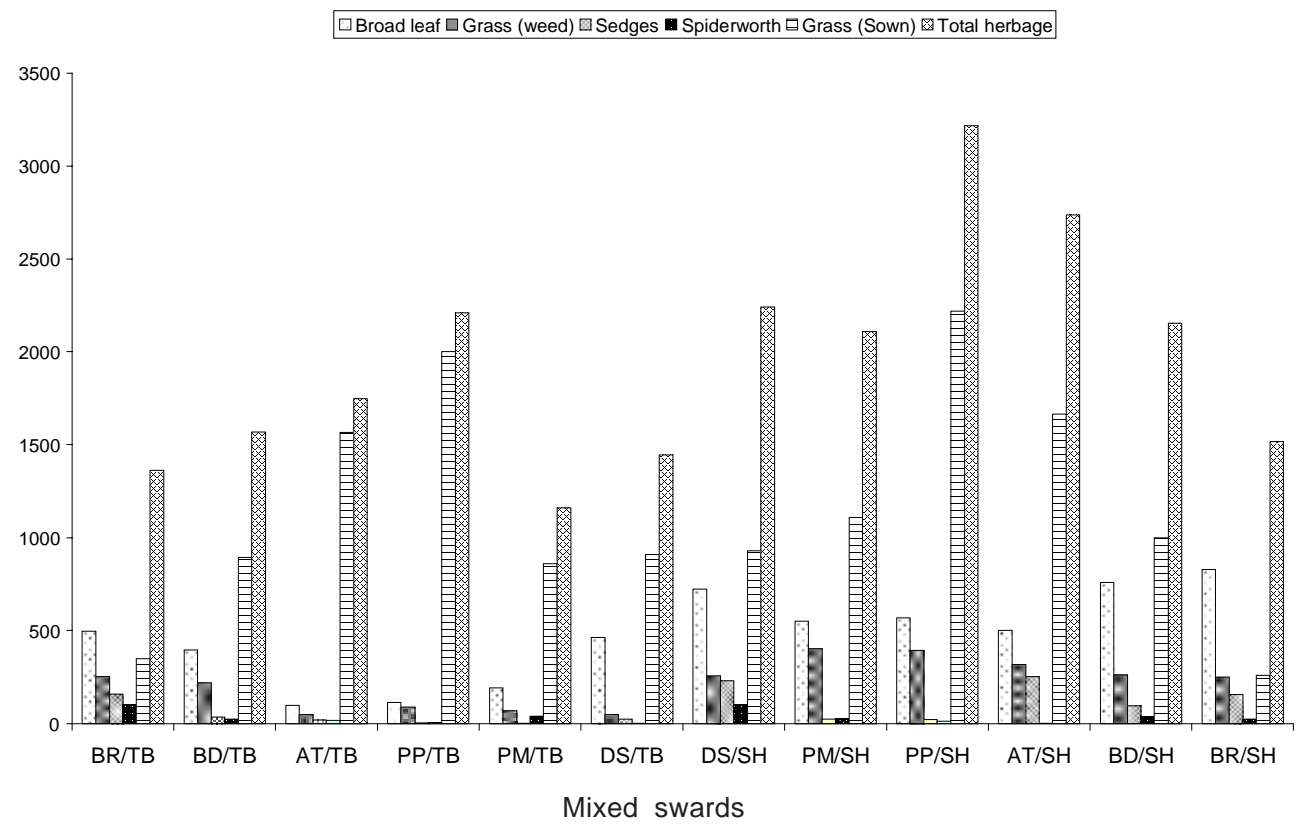

Figure 3. Dry matter yield $(\mathrm{kg} / \mathrm{ha})$ of weed types and companion forage grasses $(B R=\mathrm{B}$. ruziziensis; $T B=\mathrm{T}$. bracteolata; $A T=\mathrm{A}$. tectorum; $P P=\mathrm{P}$. purpureum; $P M=\mathrm{P}$. maximum; $D S=$ D. smutsii; $S H=\mathrm{S}$. hamata) 12 weeks after planting in 2005. (Rendimiento de materia seca $(\mathrm{kg} /$ ha) de los tipos de malas hierbas y pastos de forraje de compañía $(B R=B$. ruziziensis, $T B=$ bracteolata $T$.; $\mathrm{A}=A$. tectorum; $\mathrm{PP}=P$. purpureum; $\mathrm{PM}=P$. máxima; $\mathrm{DS}=D$. smutsii; $\mathrm{SH}=S$. hamata) 12 semanas después de la siembra en 2005).

weeds compared with other mixed swards in the experiment. Only D. smutsii (a sodforming grass) recorded a higher leaf number than the 3 bunch-forming grasses. All three bunch-forming grasses recorded higher leaf numbers than the other two sod-forming grasses. Bunch-forming grasses were taller than the sod-forming grasses as a result of their erect growth pattern. This afforded them a better opportunity to intercept adequate solar energy for photosynthetic activities which boosted their growth rate while the prostrate or semi-prostrate growth pattern of sod-forming grasses made them susceptible to a shading effect from the companion legumes (Lyon et al., 1996).

Although there are exceptions, most weeds do not compete well with a dense stand of desirable forage species. Further, to minimize the effects of weeds, pastures should be managed to favor the vigorous growth of the desired forage species (Lawal, 2000).

The bunch - forming grasses have higher dry matter yield than sod-forming grasses and competed better with weeds. The lower DM yield recorded for the sedges and spiderworth in mixed swards of $D$. smutsiil $T$. bracteolata showed that this combination was most effective in suppressing the growth of these weeds than all the other mixtures. A. tectorum/S. hamata also outperformed the other mixtures in smothering the broad-leaf and grass weeds. The ability of the bunch-forming grasses to outgrow the weeds and reduce competition for nutrients, light etc., could be responsible for their higher DM yield than for the sod- 


\section{EFFECTS OF GROWTH HABITS OF GRASSES ON WEED POPULATION AND YIELDS}

forming grasses which were slower and did not quickly form canopy over the weeds.

\section{CONCLUSIONS}

It can be concluded that the bunchforming grasses out-performed their sodforming counterparts in terms of DM yield and ability to control weeds, especially during the establishment phase in the first twelve (11) weeks after planting in the first year. However, sod-forming grasses were

\section{REFERENCES}

Bonner, J. and Galson, A.J. 1959. Principles of plant physiology. W.H. Freeman and Co. San Francisco, CA. USA.

Haynes, R.J. 1980. Competitive Aspects of grasslegume Associations. Agron Advan, 33: 227-260.

Lawal, A.O. 2000. Weed control in Guinea grass (Panicum maximum Jacq.) and cook stylo (Stylosanthes guianensis (Aubl.) Sw.) and their mixtures during establishment in South West Nigeria. Ph. D. Thesis. University of Ibadan. Ibadan. Oyo State. Nigeria.

Littell, R.C.; Freund, R.J. and Spector, P.C. 1991. SAS system for linear models. $3^{\text {rd }}$ Ed. SAS Institute. Cary, NC.

Lugo, M.D.; Ramos, R. and Liu, L.C. 1995. Research Note: Weed control in pasture establishment. $J$ Agr (University of Puerto Rico), 79: 181-182.

Lyon, D.S.; Miller, S.D. and Wicks, G.A. 1996. The future of herbicides in weed control systems of the Great Plains. J Prod Agric, 9: 209-215.

Mohammed-Saleem, M.A. 1994. Evaluation of Stylosanthes for pasture development: An overview of ILCA's experience in Nigeria. In: P.N. de Leeuw, M.A. Mohammed-Saleem and A.M. Nyamu. (Eds.). Stylosanthes as a forage and equally effective in competing with weeds in the second year once they formed dense ground cover. Grass/legume mixed sward that have the ability to form dense cover should be used as a biological weed control method.

\section{ACKNOWLEDGEMENT}

The authors are grateful to I.R. Ibitoye, B.S., of the Department of Pasture and Range Management, UNAAB for his contributions.

fallow crop. Proceedings of the Regional Workshop on the use of Stylosanthes in West Africa. 23-31 October, 1992. Kaduna. Nigeria. pp. 17-23.

Peters, E.J. and Linscott, L.D. 1988. Weeds and weed control. In: A.A. Hanson (Ed.). Alfalfa and Alfalfa improvement. Agronomy, 29: 705-735.

Semb, K. 1996. Growth characteristics of spring barley and selected weeds. I. Effects of irradiance in growth chambers. Weed Res, 36: 339-352.

Sleugh, B.; Moore, K.J.; George, J.R. and Brummer, E.C. 2000. Binary grass-legume mixtures improve yield, quality, and seasonal distribution. Agron J, 92: 24-29.

Smith, R.S. Jr.; Bouton, J.H. and Hoveland, C.S. 1992. Persistence of alfalfa under continuous grazing in pure stands and in mixture with tall fescue. Crop Sci, 32: 1259-1264.

Teitzel, J.K. and Middleton, C.M. 1980. Pasture research by South Johnstone Research Station. QDPT (Eds). Agric Br Tech, № 22.

Zannone, L.; Rotili, P.; Paoletti, R. and Scotti, C. 1986. Experimental studies of grass-legume associations. Agronomie, 6: 931-940. 